\title{
ANNOUNCEMENT
}

(C) The Japan Wood Research Society 2017

\section{The 2nd Announcement of the 68th Annual Meeting of the Japan Wood Research Society in Kyoto}

Date: March 14-16, 2018.

Venue: Kyoto Prefectural University, Shimogamo Campus (1-5, Shimogamo hangi-cho, Sakyo-ku, Kyoto, Japan) Kyoto International Conference Center (422, Iwakura osagi-cho, Sakyo-ku, Kyoto, Japan)

Time Table:

\begin{tabular}{|c|c|c|c|c|}
\hline Date & March 14 (Wed.) & \multicolumn{2}{|c|}{ March 15 (Thur.) } & March 16 (Fri.) \\
\hline Venue & $\begin{array}{c}\text { Kyoto Prefectural University, } \\
\text { Shimogamo Campus }\end{array}$ & \multicolumn{2}{|c|}{$\begin{array}{c}\text { Kyoto International } \\
\text { Conference Center }\end{array}$} & $\begin{array}{c}\text { Kyoto Prefectural University, } \\
\text { Shimogamo Campus }\end{array}$ \\
\hline Morning & Oral presentation & $\begin{array}{c}\text { Poster } \\
\text { presentation }\end{array}$ & $\begin{array}{c}\text { Exhibition } \\
\text { of related } \\
\text { companies }\end{array}$ & $\begin{array}{c}\text { Oral presentation } \\
\text { Closing ceremony }\end{array}$ \\
\hline Afternoon & Oral presentation & $\begin{array}{c}\text { Poster } \\
\text { presentation } \\
\text { JWRS awards } \\
\text { ceremony } \\
\text { Symposium }\end{array}$ & $\begin{array}{c}\text { Exhibition } \\
\text { of related } \\
\text { companies }\end{array}$ & Seminars for research groups \\
\hline Evening & Wood Science Mixer & \multicolumn{2}{|c|}{ Banquet } & \\
\hline
\end{tabular}

Due Dates:

The entry of presentation with an abstract: 17:00(JST), January 10, 2018

Early bird registration: 17:00(JST), February 6, 2018

The Japan Wood Research Society (JWRS) takes great pleasure in inviting all members of our society with an interest in the science and technology of wood to attend the 68th Annual Meeting of the JWRS that will be held from March 14 to 16, 2018, Kyoto, Japan.

The society members may take oral and poster presentations during the meeting. The symposium and the exhibition of the related companies will also be held.

For more detail information, please visit http://www.jwrs.org/wood2018/index-e.html.

Organizing Committee:

Prof. Dr. Keiji Takabe (Chief)

Prof. Dr. Yuzo Furuta (Executive Chief)

Prof. Dr. Hisashi Miyafuji (Secretary)

Associate Prof. Dr. Atsushi Tabuchi (Secretary)

Assistant Prof. Dr. Keisuke Kojiro (Secretary)

Graduate School of Life and Environmental Sciences, Kyoto Prefectural University

E-mail: wood2018@jwrs.org 
Mokuzai Gakkaishi (Journal of the Japan Wood Research Society)

Mokuzai Gakkaishi is another official journal of the Japan Wood Research Society. This journal publishes original articles, notes, review articles, and announcements from the Society in Japanese but with English abstracts, tables, and figure captions for original reports. Contents of the latest issue of Mokuzai Gakkaishi are as follows:

Volume 63 Number 52017

\section{Category II}

Saki Komine, Kei Maeda, Satoshi Shida

Relationship between epidermis color and vibration properties of Arundo donax for bassoon reed materials

Masaaki Yuki, Takao Momoi, Jun Kobayashi, Hiroya Ohbayashi

Measurement of wood vibrational properties by the central exciting method

Taku Okuda, Toshinori Nakagawa, Tomoya Murano, Yu Miyoshi, Hirohito Kamei, Takao Sasaki, Yasuhiro Saigusa, Yoshiyuki Wada, Syunji Minato, Syouichi Sakai, Taizou Chiri, Noboru Fujimoto,

Kuniyoshi Shimizu

Effect of heat drying treatment on extracts of sugi (Cryptomeria japonica) board: quantitative change of terpenes by moderate-temperature drying treatments

\section{Category III}

Kaori Mimura, Tadashi Hara, Hideo Kato, Masahiro Noguchi, Akihisa Hirata, Kenji Honda, Toshiaki Matsuhashi

Reuse of wood used in underground construction and suggestion of a method of differentiation 